\title{
MENINGKATKAN KETERAMPILAN MEMBACA PEMAHAMAN BAHASA INGGRIS MELALUI METODE SQ4R
}

\begin{abstract}
Herlina
e-mail: herlina.unj.id@gmail.com

PGSD Universitas Negeri Jakarta

Jalan Rawamangun Muka Jakarta Timur

Abstrak: Penelitian ini bertujuan untuk memperoleh data mengenai peningkatan keterampilan membaca pemahaman bahasa Inggris melalui metode SQ4R siswa kelas III SDS Labschool Setiabudi Jakarta Selatan. Subjek penelitian adalah siswa kelas III pada semester II tahun ajaran 2014/2015. Penelitian ini dilaksanakan dengan menggunakan model Kemmis dan Mc. Taggart yang dilaksanakan dengan tahap perencanaan, pelaksanaan, observasi, dan refleksi. Hasil penelitian dengan menggunakan metode SQ4R menunjukkan data yang diperoleh dari tes evaluasi membaca pemahaman siswa yang mendapat skor $\geq 75$ pada siklus I $55,55 \%$ dan pada siklus II diperoleh $83,33 \%$. Sedangkan pemantau aktifitas guru dan siswa pada siklus I pertemuan pertama $55 \%$ dan pertemuan kedua $70 \%$ sedangkan siklus II pertemuan pertama $85 \%$ dan pertemuan kedua $90 \%$. Dengan demikian membaca pemahaman dengan metode SQ4R dapat meningkatkan keterampilan membaca pemahaman siswa kelas III SDS Labschool Setia Budi Jakarta Selatan.
\end{abstract}

Kata-kata kunci: keterampilan membaca, pemahaman bahasa inggris, SQ4R.

\section{IMPROVING ENGLISH READING COMPREHENSION SKILL BY SQ4R METHOD}

\begin{abstract}
This research aims at obtaining data on improving English reading comprehension skill in Grade III, Labschool Primary School, Setiabudi, South Jakarta. The research subjects were the students of Grade III in the second semester of 2014/2015 school academic year. The research model used Kemmis and Mc. Taggard model covering planning, implementation, observation, and reflection. The data of reading comprehension evaluation showed that in the first cycle $55.5 \%$ of the students gained $>75$ and in the second cycle $83.33 \%$ of them gained $>75$. While based on the monitoring data, the activities of the teacher and the students were $55 \%$ in the first meeting of the cycle I and increased to $85 \%$ in the first meeting of the cycle II. Therefore, SQ4R method can improve English reading comprehension skill of the Grade III students in Labschool Primary School, Setiabudi, South Jakarta.
\end{abstract}

Keywords: reading skill, English comprehension, SQ4R.

\section{PENDAHULUAN}

Keterampilan membaca sangat penting dalam kehidupan manusia. Keterampilan membaca tersebut dapat dikembangkan melalui pendidikan formal yaitu sekolah, yang dimulai dari sekolah dasar sampai perguruan tinggi. Pada jenjang pendidikan dasar keterampilan membaca memerlukan suatu proses pembelajaran yang baik dan maksimal. Dikatakan demikian karena sekolah dasar merupakan lembaga pendidikan formal yang pertama dalam dunia pendidikan yang menjadi dasar atau landasan untuk menentukan keberhasilan seseorang ke tingkat pendidikan yang lebih tinggi.
Membaca pemahaman merupakan salah satu aspek yang menjadi tujuan utama dari pengajaran membaca di sekolah dasar. Membaca pemahaman adalah dasar untuk memahami berbagai bidang studi. Begitupun dalam bahasa Inggris, untuk memahaminya diperlukan keterampilan membaca dengan baik, seseorang tidak dapat memahami apa yang orang lain maksudkan dalam tulisannya.

Pembelajaran bahasa Inggris merupakan salah satu mata pelajaran yang dianggap sukar karena bahasa Inggris bukan bahasa Ibu atau bahasa nasional yang digunakan sehari-hari, hal ini menyebabkan kebosanan. Kondisi tersebut 
berimplikasi pada rendahnya tingkat penguasaan siswa terhadap materi pembelajaran bahasa Inggris. Berdasarkan pengamatan yang dilakukan, guru lebih sering menggunakan pendekatan belajar konvensioanal, pendekatan yang berpusat pada guru bukan pendekatan yang berpusat pada siswa. Siswa kurang mendapat kesempatan mempraktekan ilmu yang didapat, sehingga siswa mengalami kesulitan mempraktekannya dengan benar. Guru lebih sering mempraktekan secara klasikal daripada individual.

Dalam pembelajaran bahasa Inggris ada banyak cara untuk melatih siswa yang tidak terbiasa menggunakan bahasa Inggris dalam kehidupannya sehari-hari agar tertarik dan mau belajar bahasa Inggris. Ada beberapa metode pelajaran yang dapat digunakan dalam pembelajaran bahasa Inggris kegiatan membaca adalah SQ4R (Survey, Question, Read, Recite, Record, dan Review), Speed Reading, Aloud Reading. SQ4R merupakan metode yang dapat membantu siswa memahami bahan bacaan dalam pelajaran bahasa Inggris.

Keterampilan membaca pemahaman adalah sebuah proses interaktif yang melibatkan pembaca, bacaan dan konteks. Keterampilan ini melibatkan kemampuan untuk memperoleh makna dari teks tertulis seperti yang dinyatakan oleh Silliman dan Wilkinson (2007) "Reading comprehension is generally defined as the ability to acquire meaning from written text". Melalui proses membaca pemahaman (reading comprehension), para pembaca mendapatkan pemahaman dari teks yang dibacanya yang berkaitan dengan informasi maupun kosakata baru.

Adapun keterampilan yang bersifat pemahaman adalah proses penangkapan makna dari kata atau dari kalimat yang dibaca. Keterampilan ini berada pada urutan yang lebih tinggi. Aspeknya mencakup: memahami pengertian sederhana; memahami signifikan atau makna (maksud dan tujuan pengarang reaksi pembaca); evaluasi atau penilaian isi; serta kecepatan membaca yang fleksibel, yang mudah disesuaikan dengan keadaan. Untuk mencapai tujuan yang diinginkan dalam keterampilan pemahaman, aktivitas yang paling tepat adalah membaca dalam hati. Salah satu aspek keterampilan berbahasa yaitu keterampilan membaca yang didasari oleh kemampuan membaca, mampu membaca tidak berarti secara otomatis terampil membaca. Menurut
Juel dalam Bastino (2007) membaca adalah proses untuk mengenal kata dan memadukan arti kata dalam kalimat dan struktur bacaan. Membaca merupakan keterampilan untuk membuat suatu penafsiran terhadap bahan yang dibaca.

Menurut Crawley dan Mountain, membaca pada hakikatnya adalah suatu yang rumit yang melibatkan banyak hal, tidak hanya sekedar melafalkan tulisan, tetapi juga melibatkan aktivitas visual, berpikir, psikolingualistik, dan metakognitif. Sebagai proses visual membaca merupakan proses menerjemahkan simbol tulis (huruf) ke dalam katakata lisan, sebagai suatu proses berpikir, membaca mencakup aktivitas pengenalan kata, pemahaman literal, interpretasi, membaca kritis dan pemahaman kreatif. Pengenalan kata bisa berupa aktivitas membaca kata-kata dengan menggunakan kamus. Jadi membaca yaitu suatu proses berpikir yang kompleks atau rumit, yang melibatkan banyak hal tidak hanya sekedar tulisan atau lisan karena juga melibatkan sikap, pikiran dan pengalaman untuk memusatkan perhatian pada setiap bacaan.

Hafner dan Jolly (2007) menyatakan bahwa pemahaman adalah kemampuan seseorang untuk mengerti, memahami, untuk menyerap dengan akal. Pemahaman dibagi ke dalam tiga kategori yaitu pemahaman harfiah, penafsiran, dan reaksi kritis. Tujuannya agar pembaca dapat memahami isi teks bacaan. Carlson berpendapat bahwa kecepatan dan pemahaman memiliki korelasi atas bahanbahan bacaan yang sulit dapat diabaikan. Carlson menemukan bahwa, pada tingkat kecerdasan tinggi, para pembaca cepat ternyata paling baik dalam memahami bacaan. Pembaca lambat seringkali merasa yakin bahwa pembaca cepat lebih rendah tingkat pemahamannya. Akan tetapi sebenarnya tidak demikian, karena pembaca cepat melihat deretan kata-kata sebagai bagian dari keseluruhan kalimat atau paragraf, tidak terpisah agar dimengerti isi dan maknanya, mereka melihat kata-kata yang ada dalam konteks keseluruhan kalimat, mereka membaca dengan cepat dan sekaligus berkonsentrasi pada isi bacaan.

McLaughlin dan Allen (2007), prinsip-prinsip membaca yang didasarkan pada penelitian yang paling mempengaruhi pemahaman membaca adalah sebagai berikut: (1) pemahaman merupakan proses konstruktivitas sosial, (2) keseimbangan kemahiraksaraan adalah kerangka kerja kurikulum yang membantu perkembangan pemahaman, (3) 
guru membaca yang professional mempengaruhi belajar siswa, (4) pembaca yang baik memegang peranan yang strategis dan berperan aktif dalam proses membaca, (5) membaca hendaknya terjadi dalam konteks yang bermakna, (6) siswa menemukan manfaat membaca yang berasal dari berbagai teks pada berbagai tingkat kelas, (7) perkembangan kosakata dan pembelajaran mempengaruhi pemahaman membaca, (8) pengikutsertaan adalah suatu faktor kunci pada proses pemahaman, (9) strategi dan keterampilan membaca bisa diajarkan, serta (10) asesmen yang dinamis menginformasikan pembelajaran membaca pemahaman.

Dalam perkembangan bahasa, Piaget dalam Cox (1999:h.50) menyatakan bahwa "language development is an aspect of general cognitive development". Menurutnya, perkembangan bahasa adalah sebuah aspek dari keseluruhan perkembangan kognitif. Bahasa juga mempengaruhi tingkat kognitif siswa. Pada rentang usia ini siswa dapat menggunakan bahasa secara simbolik, mengerti konsep, penggunaan bahasa secara fleksibel dan artikulasi yang mulai terdengar secara benar. Finochiaro dalam Tarigan reading adalah bringing meaning to and getting meaning from printed or written material, memetik serta memahami arti atau makna yang terkandung di dalam bacaan. Terlihat jelas bahwa membaca adalah proses yang bersangkutan dengan bahasa. Oleh karenanya, anak haruslah dibantu untuk menanggapi atau member respon terhadap lambang-lambang visual menggambarkan tanda auditori yang sama yang telah mereka pelajari.

Salah satu teknik membaca yang cukup sering digunakan adalah teknik Survey, Question, Read, Recite, dan Review (SQ4R). SQ4R adalah suatu teknik membaca untuk menemukan ideide pokok dan pendukungnya serta membantu mengingat agar tahan lebih lama melalui lima langkah kegiatan, yaitu survey, question, read, recite, and review. Menurut Laksono dkk (2007: h.18) karakteristik metode SQ4R adalah: (1) sebelum membaca, pembaca menyurvei terlebih dahulu judul buku, nama pengarang, rangkuman, dan daftar pustaka; (2) merumuskan beberapa pertanyaan untuk diri sendiri tentang bacaan tersebut yang diharapkan jawabannya ada dalam buku itu; (3) dengan bekal pertanyaan-pertanyaan tadi, pembaca memulai kegiatan membaca; (4) untuk mengetahui penguasaan terhadap bacaan, setelah membaca, pembaca melakukan kegiatan mengutarakan kembali isi bacaan dengan kata-kata sendiri; dan (5) kegiatan membaca dengan metode SQ4R diakhiri dengan kegiatan meninjau kembali atau mengulang kembali apa yang sudah dibaca.

Langkah-langkah dalam menerapkan teknik survei adalah sebagai berikut. Pertama, sebelum membaca (pree reading), pergunakan bab survei untuk mengaktifkan pengetahuan terdahulu anda (prior knowledge) terhadap subjek bacaan yang akan anda baca. Cobalah mengingat kembali apa yang telah anda ketahui tentang subjek bacaan untuk mengantisipasi ide pokok dari bab tersebut. Pergunakanlah juga survei untuk memprediksi pola pikir dominan sang penulis. Lakukan survei untuk mengantisipasi bagian yang mana dari bab tersebut yang paling sulit atau paling menantang untuk dipelajari. Kedua, selama kegiatan membaca (while reading) pergunakan survei sebagai panduan untuk menentukan apa yang penting anda pelajari. Garis bawahi, atau tandai informasi-informasi kunci yang telah identifikasi dalam survei. Ketiga, setelah membaca (after reading), pergunakan survei untuk memonitor keefektifan membaca anda. Dalam hal ini teslah kemampuan anda untuk mengingat kembali informasi-informasi kunci. Jika hasil tes tidak memuaskan segera tinjau kembali materimateri yang anda tidak mampu ingat.

\section{METODE PENELITIAN}

Penelitian ini merupakan penelitian tindakan kelas (classroom action reasearch) dengan menggunakan siklus (putaran spiral) yang mengacu pada model Kemmis dan Mc. Taggart yang terdiri dari empat komponen, yaitu: Perencanaan (planning), tindakan (action), pengamatan (obervating), dan refleksi (reflection). Model Kemmis dan Mc. Taggart merupakan pengembangan dari konsep dasar yang diperkenalkan oleh Kurt Lewin. Komponen tindakan dengan pengamatan dijadikan satu kesatuan. Disatukannya kedua komponen tersebut disebabkan oleh adanya kenyataan bahwa antara penerapan tindakan dan pengamatan merupakan dua kegiatan yang tidak dapat dipisahkan. Untuk lebih jelasnya dapat dilihat pada gambar 1 . 


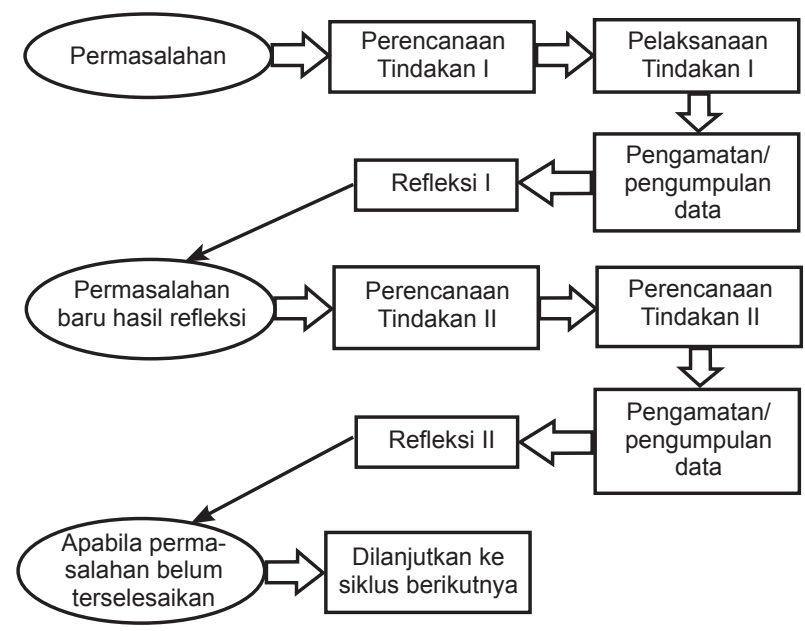

Gambar 1. Grafik desain tindakan kelas menurut Kemmis dan McTaggart

Penelitian dilakukan pada semester genap tahun ajaran 2014/2015 di SDS Labschool
PGSD Setiabudi. Teknik pengumpulan data digunakan untuk mendapatkan data penelitian adalah dengan cara sebagai berikut. Pertama, melalui observasi langsung dengan menggunakan lembar pengamatan untuk pengambilan data proses pembelajaran dengan menggunakan metode Survey, Question, Read, Recite, Record, dan Review. Observasi yang digunakan adalah Observasi langsung yang dilaksanakan mulai dari awal kegiatan sampai akhir kegiatan. Kedua, catatan lapangan untuk mencatat setiap tindakan baik siswa maupun guru, baik yang sifatnya positif maupun yang sifatnya negatif. Ketiga, dokumentasi berupa foto-foto selama kegiatan pembelajaran berlangsung. Keempat, teknik pengumpulan data yang dilakukan oleh peneliti yaitu teknik tes untuk melihat seberapa besar peningkatan kemampuan peserta didik.

\section{HASIL DAN PEMBAHASAN}

\section{Perencanaan (Planning)}

Terdapat dua belas kegiatan di dalam perencanaan. Pertama, menyusun rencana pelaksanaan pembelajaran dengan tujuan pembelajaran yang sesuai dengan materi yang akan dipelajari. Kedua, menentukan kompetensi yang berhubungan dengan materi yang akan dipelajari. Ketiga, mengembangkan skenario pembelajaran. Keempat, melaksanakan tugas rutin guru (mengkondisikan kelas). Kelima, melalui tahap Survey, guru membimbing siswa dalam mengamati teks/bahan bacaan bergambar yang ditulis dalam bahasa Inggris dan membahas kosakata yang baru terdapat dalam teks yang diamati.

Keenam, melalui tahap Question, guru membimbing siswa untuk memperhatikan pertanyaan-pertanyaan tentang teks yang oleh siswa yang telah disiapkan oleh guru sebelumnya sebagai prediksi pemahaman membaca mereka. Ketujuh, melalui tahap Read, guru membimbing siswa dalam melakukan tahap membaca. Dalam tahap ini guru terlebih dahulu memberikan model cara membaca bahan bacaan dalam bahasa Inggris dengan pelafalan yang benar dan setelahnya memfasilitasi siswa untuk membaca dalam hati untuk pemahaman. Kedelapan, melalui tahap Recite, guru membimbing siswa dalam menjawab pertanyaan-pertanyaan. Kesembilan, melalui tahap Record, guru membimbing siswa dalam menandai atau menggaris bawahi jawaban dalam teks/bahan bacaan. Kesepuluh, melalui tahap Review, guru membimbing siswa menyampaikan/membacakan jawaban-jawaban mereka. Kesebelas, guru memberikan kesempatan kepada siswa untuk mengkonfirmasi kemampuan mereka dalam menggunakan teknik SQ4R untuk membaca pemahaman yang sudah dipelajari dengan mengerjakan tugas/LKS secara mandiri. Keduabelas, memberikan tindak lanjut (pengayaan,penugasan atau pekerjaan rumah). Media yang digunakan selama kegiatan berlangsung yaitu flashcards yang berisi gambar-gambar tentang bacaan, teks/ bacaan, dan LKS.

\section{Pelaksanaan Tindakan (Acting)}

Tahap pelaksanaan tindakan ini merupakan tahap realisasi dari tahap perencanaan yang telah disusun dan disepakati bersama kolabolator. Peneliti melaksanakan pembelajaran membaca pemahaman melalui metode SQ4R di kelas III Labschool Kecamatan Setiabudi Jakarta Selatan. Pelaksanaan tindakan dilakukan selama 2 siklus, setiap siklus terdiri dari 2 pertemuan. Setiap pertemuan dilakukan selama 2 jam pelajaran $(2 \times 35$ menit). Adapun pelaksanaan tindakan disesuaikan dengan jadwal pelajaran yang sudah ada.

\section{Pengamatan Tindakan (Observing)}

Dalam proses pengamatan pengamat mempunyai dua tugas yaitu: (1) mengamati proses tindakan pembelajaran yang dilakukan oleh guru apakah sudah sesuai dengan perencanaan 
tindakan yang dibuat atau belum, dan (2) melakukan pengamatan terhadap seberapa besar peningkatan kemampuan membaca pemahaman siswa. Setelah menggunakan metode SQ4R pengamatan dilakukan dengan cara pengamat menyimak proses tindakan pembelajaran yang dilakukan oleh subjek penelitian mulai dari persiapan hingga akhir proses tindakan setiap kegiatan yang dilakukan oleh subjek penelitian harus disimak secara teliti dan harus dicatat agar tidak terjadi kekeliruan dalam pelaporan hasil pengamatan. Catatan yang dimaksud disini adalah catatan lapangan yang berfungsi untuk mendokumentasikan seluruh rangkaian kegiatan tindakan pembelajaran secara lengkap.

Selain membuat catatan lapangan berupa data hasil pengamatan secara tertulis, pengamat juga membuat dokumentasi berupa foto yang diambil melalui kamera. Tujuan dari pembuatan dokumentasi berupa foto yaitu agar setiap kegiatan yang dilakukan dalam tindakan dapat ditampilkan dan disajikan dengan jelas dan nyata. Foto ini digunakan sebagai data pelengkap dari data catatan lapangan. Semua data atau dokumentasi hasil pengamatan baik kegiatan atau proses pembelajaran maupun peningkatan kemampuan peserta didik dijadikan sebagai acuan untuk melakukan tindakan pada siklus ke II.

Refleksi Tindakan (Reflecting)

Setelah tindakan perbaikan selesai dilakukan, maka kegiatan selanjutnya adalah refleksi tindakan. Refleksi tindakan merupakan kegiatan yang dilakukan oleh peneliti dan teman sejawat atau kolabolator dalam rangka mengulas secara kritis dengan cara mendiskusikan perubahan yang terjadi setelah dilakukan tindakan perbaikan. Perubahan disini meliputi proses pembelajaran yang dilakukan oleh guru dan kemampuan membaca pemahaman peserta didik. Kegiatan yang dilakukan dalam refleksi tindakan ini yaitu analisis data dan interpretasi data yang diperoleh dalam penelitian tindakan. Refleksi tindakan ini dilakukan dengan tujuan untuk menganalisis sejauh mana ketercapaian proses tindakan pembelajaran yang dilakukan oleh peneliti, selain itu, refleksi tindakan juga bertujuan untuk mengetahui kendala apa saja yang dihadapi sehingga proses tindakan pembelajaran belum berhasil.

Dalam rangka mengumpulkan data tentang kemampuan peserta didik dalam menyelesaikan soal maka peneliti membuat kisi-kisi instrumen kemampuan membaca pemahaman yang diberikan kepada peserta didik setelah proses tindakan pembelajaran selesai dilaksanakan pada setiap siklusnya.Kisi-kisl untuk mengukur variabel kemampuan membaca pemahaman disajikan pada bagian ini:

\section{Pembahasan}

Berdasarkan hasil analisis data dari hasil tindakan siklus I dan siklus II terlihat adanya peningkatan dari semua data yang diambil. Kekurangan-kekurangan yang terjadi dan teramati pada siklus I seperti siswa masih kurang aktif dan kurang berani untuk mengajukan pendapat atau pernyataan selama proses pembelajaran, siswa kurang teliti dalam mengerjakan tugas, konsentrasi siswa masih kurang, serta guru yang kurang mengelaborasi kemampuan siswa dalam mengaplikasikan metode SQ4R sehingga kurang member pendalaman pada siswa yang membutuhkan penjelasan dan latihan lebih, telah dapat teratasi pada siklus II. Pada siklus II secara keseluruhan terlihat para siswa siap dan sangat terlibat aktif dalam melaksanakan pembelajaran membaca pemahaman dengan metode SQ4R. Peneliti juga melakukan persiapan yang matang sehingga dapat melaksanakan pembelajaran dan membimbing siswa dalam melaksanakan pembelajaran membaca pemahaman dengan metode SQ4R dengan baik. Semua membuat siklus II dapat mencapai target penelitian. Secara detail data yang diperoleh, kita akan menemukan bahwa hasil tes membaca pemahaman (reading comprehension test) pada siklus I menunjukan baru 10 orang siswa dari total 18 orang siswa atau sekitar $55,55 \%$ yang mendapat skor tesmembaca pemahaman $\geq 75$. Sedangkan pada siklus II telah terjadi peningkatan tes membaca pemahaman yang signifikan sebesar $27,78 \%$ sehingga jumlah siswa yang mendapatkan skor membaca pemahaman $\geq 75$ bertambah menjadi 15 orang atau sekitar $83,33 \%$.

Adapun data pemantau aktivitas guru dan siswa dengan metode SQ4R pada siklus I pertemuan 1 dan 2 di Labschool Setiabudi Jakarta Selatan mendapatkan persentase sebesar $55 \%$ dan $70 \%$ dari 20 pernyataan dalam instrumen pemantau aktivitas guru dan siswa. Sedangkan pada siklus II pada pertemuan 1 dan 2 telah persentase sebesar $85 \%$ menjadi $90 \%$. Pada Siklus I dan siklus II terjadi peningkatan sebesar $35 \%$. 
Dengan demikian, maka maka dapat dikatakan membaca pemahaman melalui metode SQ4R telah meningkat. Peningkatan ini menunjukan bahwa identifikasi dan terhadap temuan-temuan masalah yang terjadi pada setiap siklus telah ditemukan pemecahannya dan menunjukan hasil yang optimal.

\section{PENUTUP}

\section{Kesimpulan}

Berdasarkan deskripsi dan analisis data, maka dapat disimpulkan bahwa: Keterampilan membaca pemahaman siswa kelas III Labschool Kec. Setiabudi Jakarta Selatan dengan menggunakan metode SQ4R menunjukan peningkatan kemampuan membaca pemahaman siswa, dengan nilai ratarata pada siklus I 68,33 menjadi 83,61 pada siklus II. Penggunaan metode SQ4R dalam pembelajaran bahsa Inggris khusunya pada aspek membaca memudahkan siswa memahami isi bacaan. Secara keseluruhan pembelajaran membaca pemahaman melalui metode SQ4R dapat memberi dampak yang lebih besar terhadap hasil pembelajaran membaca pemahaman, oleh karena itu pembelajaran dengan menggunakan metode SQ4R layak digunakan di Sekolah Dasar. Metode SQ4R dalam pembelajaran bahasa Inggris khususnya pada aspek membaca dapat membuat siswa untuk berpikir secara sistematis sesuai langkah-langkah metode SQ4R dan dengan mudah mampu memahami isi bacaan.

Kegiatan belajar mengajar yang dilakukan guru akan lebih efektif jika guru dapat memilih dan menggunakan metode, pendekatan, atau model pembelajaran yang sesuai dengan karakteristik siswa maupun bidang studi yang diajarkan. Metode SQ4R ini dapat diterapkan bila dalam pembelajaran bahasa Inggris, guru mengalami kesulitan pada proses pembelajaran, di mana hasil belajar membaca pemahaman siswa rendah. Strategi pembelajaran ini dapat memberikan dampak positif pada siswa antara lain siswa yang tadinya tidak menyukai kegiatan membaca menjadi suka, siswa yang tadinya tidak memahami bacaan yang dibacanya menjadi paham aka nisi bacaan. Dalam menjawab pertanyaan siswa mencoba untuk mengingat teks bacaannya. Pemanfaatan metode SQ4R dalam proses pembelajaran dapat mendorong siswa untuk belajar secara aktif, menyenangkan untuk memperoleh hasil belajar yang lebih baik lagi. Kondisi belajar seperti ini dapat meningkatkan hasil belajar siswa dalam pembelajaran bahasa Inggris. Keuntungan yang diperoleh dari model pembelajaran yaitu jika metode pembelajajan SQ4R ini dapat diimplementasikan secara utuh maka hasil belajar siswa bukan hanya sekedar hafalan namun berupa pengetahuan, pemahaman konsep-konsep yang didapat selama proses belajar sehingga proses pembelajaran bermakna bagi siswa.

\section{Saran}

Berdasarkan penjabaran di atas, maka sebaliknya para guru menggunakan metode SQ4R sebagai salah satu metode pembelajaran yang dapat digunakan meningkatkan keterampilan membaca pemahaman siswa. Dengan demikian, diharapkan penerapan metode SQ4R dapat dilaksanakan dengan baik sehingga hasil yang diharapkan dapat tercapai dengan maksimal.

\section{DAFTAR PUSTAKA}

Ahuja, P. (2004). Membaca secara efektif dan efesien. Bandung: PT.Kiblat buku utama.

Arikunto,S., dkk.(2009). Penelitian tindak kelas. Jakarta: Bumi Aksara.

Bastiono. (2007). Pembinaan minat baca. Jakarta: Universitas Terbuka.

Cox, C. (1999). Teaching language art : a students with language approach.Classroom. USA: Allyn and Bacon.

Dimyati.,\& Mudjiono. (2006). Belajar dan pembelajaran. Jakarta: Rineka Cipta.

Farida. (2010). Upaya peningkatan membaca pemahaman anak kelas iii sekolah dasar (usia 7-8 tahun) melalui kegiatan. Disertasi: tidak diterbitkan. Jakarta.
Hopkins, D. (1993). A teacher guide to classroom research. Buckingham: Open University Press

Kusuma, W., \& Dedi, D. (2010). Mengenal penelitian tindakan kelas. Jakarta: Indeks.

Laksono, K., dkk. (2007). Membaca 2. Jakarta: Universitas Terbukas.

Putrawan, M.,\&Akbar, M. (2000). Penelitian tindakan kelas. Jakarta: Universitas Negeri Jakarta.

Rahim, F. (2005). Pengajaran membaca sekolah dasar. Jakarta: Bumi Aksara.

Rahmah, Siti, Anggun. (2011). Peningkatan kemampuan membaca pemahaman melalui metode mind map pada siswa kelas IV SDN Tugu Utara Jakarta Utara. Jakarta. 2 
Silliman, E.R.,\& Wilkinson, L.C. (2007). Language and literacy learning in schools. New York: The Guildford Press.

Soedaeso. (2010). Speed reading sistem membaca cepat dan efektif. Jakarta: PT Gramedia Pustaka Utama.

Suyitno. (1986). Teknik pengajaran apersepsi puisi dan kemampuan berbahasa. Yogyakarta:
Yudhistira.

Tarigan, H. G. (2008). Membaca sebagai suatu keterampilan berbahasa. Bandung: Angkasa.

Tarigan, H. G. (1985). Menyimak Sebagian Suatu Keterampilan Berbahasa. Bandung: Angkasa.

Wina, S. (2009). Penelitian tindakan kelas. Bandung: Kencana Perdana Media Group. 